\title{
Mechanisms of Adaptation to Chronic Respiratory Acidosis in the Rabbit Proximal Tubule
}

\author{
Reto Krapf \\ Department of Medicine, Cardiovascular Research Institute, University of California, San Francisco, California $94143-0532$
}

\begin{abstract}
The hyperbicarbonatemia of chronic respiratory acidosis is maintained by enhanced bicarbonate reabsorption in the proximal tubule. To investigate the cellular mechanisms involved in this adaptation, cell and luminal $\mathrm{pH}$ were measured microfluorometrically using (2",7')-bis(carboxyethyl)-(5,6)-carboxyfluorescein in isolated, microperfused $S_{2}$ proximal convoluted tubules from control and acidotic rabbits. Chronic respiratory acidosis was induced by exposure to $10 \% \mathrm{CO}_{2}$ for $52-56 \mathrm{~h}$. Tubules from acidotic rabbits had a significantly lower luminal pH after $1-\mathrm{mm}$ perfused length (7.03 \pm 0.09 vs. $7.26 \pm 0.06$ in controls, perfusion rate $=10 \mathrm{nl} / \mathrm{min})$. Chronic respiratory acidosis increased the initial rate of cell acidification $\left(\mathrm{dpH}_{\mathrm{i}} / \mathrm{d} t\right)$ in response to luminal sodium removal by $63 \%$ and in response to lowering luminal pH (7.4-6.8) by 69\%. Chronic respiratory acidosis also increased $\mathrm{dpH}_{\mathrm{i}} / \mathrm{d} \boldsymbol{t}$ in response to peritubular sodium removal by $63 \%$ and in response to lowering peritubular pH by $73 \%$. In conclusion, chronic respiratory acidosis induces a parallel increase in the rates of the luminal $\mathrm{Na} / \mathrm{H}$ antiporter and the basolateral $\mathrm{Na} /\left(\mathrm{HCO}_{3}\right)_{3}$ cotransporter. Therefore, the enhanced proximal tubule reabsorption of bicarbonate in chronic respiratory acidosis may be, at least in part, mediated by a parallel adaptation of these transporters.
\end{abstract}

\section{Introduction}

The high plasma bicarbonate concentration in chronic respiratory acidosis is maintained, at least in part, by an enhanced tubular bicarbonate reabsorption in the proximal nephron (1). In the mammalian proximal tubule, transcellular bicarbonate reabsorption involves proton secretion into the luminal fluid. The intracellular bicarbonate thus generated is secreted into the peritubular space across the basolateral cell membrane. On the luminal side, proton secretion is effected by a $\mathrm{Na} / \mathrm{H}$ antiporter and by a putative H-ATPase. On the basolateral side, bicarbonate can be transported via a $\mathrm{Na} /\left(\mathrm{HCO}_{3}\right)_{3}$ cotransporter or via chloride-coupled transporters. The overwhelming majority of bicarbonate reabsorption and cell $\mathrm{pH}$ regulation in the proximal tubule is dependent on sodium (2-8) while chloride removal does not affect the rates of bicarbonate reabsorption and the regulation of cell $\mathrm{pH}$ by acute changes in ambient $\mathrm{PCO}_{2}(4,7,8)$. Thus, the luminal $\mathrm{Na} / \mathrm{H}$ antiporter and the

Address reprint requests to Dr. Krapf at his present address: Department of Medicine, Insel University Hospital, BHH C, Bern, Switzerland $\mathrm{CH}-3010$.

J. Clin. Invest.

(c) The American Society for Clinical Investigation, Inc.

0021-9738/89/03/0890/07 \$2.00

Volume 83, March 1989, 890-896 basolateral $\mathrm{Na} /\left(\mathrm{HCO}_{3}\right)_{3}$ cotransporter are probably the two most important transporters involved in both transcellular bicarbonate transport and the cell $\mathrm{pH}$ response to changes in ambient $\mathrm{PCO}_{2}$.

Enhanced proximal bicarbonate reabsorption has been observed in the rat in chronic respiratory acidosis (1) and necessitates similar degrees of increase in the rates of luminal proton secretion and of basolateral bicarbonate exit. Therefore, the present studies were designed to examine whether chronic respiratory acidosis affects the rates of the luminal $\mathrm{Na} / \mathrm{H}$ antiporter and the basolateral $\mathrm{Na} /\left(\mathrm{HCO}_{3}\right)_{3}$ cotransporter. In vesicle studies, increased $\mathrm{Na} / \mathrm{H}$ antiporter activity has been reported by one group (9), but not confirmed by others $(10,11)$. Animals in which chronic respiratory acidosis was induced were compared to controls. To determine whether proximal acidification is stimulated by respiratory acidosis in the rabbit, luminal $\mathrm{pH}$ was measured fluorometrically in isolated microperfused proximal convoluted tubules (PCT). ${ }^{1}$ The transport activities of the $\mathrm{Na} / \mathrm{H}$ antiporter and the $\mathrm{Na} /\left(\mathrm{HCO}_{3}\right)_{3}$ cotransporter were analyzed by the microfluorometric determination of cell $\mathrm{pH}$. The results show that chronic respiratory acidosis stimulates acidification in the rabbit PCT and induces an increase in the rate of the luminal $\mathrm{Na} / \mathrm{H}$ antiporter which is quantitatively paralleled by a similar increase in the rate of the basolateral $\mathrm{Na} /\left(\mathrm{HCO}_{3}\right)_{3}$ cotransporter. The studies suggest that these two transporters mediate, at least in part, the enhanced rate of tubular bicarbonate reabsorption in the proximal nephron in response to chronic respiratory acidosis.

\section{Methods}

To induce chronic respiratory acidosis female New Zealand White rabbits (body weight about $1.5 \mathrm{~kg}$ ) were exposed to $10 \% \mathrm{CO}_{2}$ (air-balanced) in an environmental chamber for 52-56 h. Humidity and temperature were measured continuously. Gas samples from the chamber were measured three times daily to ensure that the $10 \% \mathrm{CO}_{2}$ atmosphere was constant. Littermate rabbits breathing room air served as controls. The animals were allowed free access to commercial rabbit laboratory diet and water. Normal animals consumed $115 \pm 11$ and acidotic rabbits consumed $101 \pm 14(n=10$, NS). Arterial blood samples were collected from an ear artery. During this procedure acidotic rabbits were continuously exposed to $10 \% \mathrm{CO}_{2}$ (face mask) while normal rabbits breathed room air. Bladder urine was obtained after sacrificing the animals and analyzed with a dipstick (Multistix, Miles Laboratories, Inc., Elkhart, IN).

After obtaining the blood sample, the rabbits were killed by decapitation, the kidneys were quickly removed and cut into thin $(\sim 1-\mathrm{mm})$ coronal slices. PCT segments were dissected in cooled $\left(4^{\circ} \mathrm{C}\right)$ control solution of the respective experiments (Table I). Only $S_{2}$ segments of

1. Abbreviations used in this paper: $\mathrm{BCECF},\left(2^{\prime \prime}, 7^{\prime}\right)$-bis-(carboxyethyl)$(5,6)$-carboxyfluorescein; BCECF-AM, acetoxymethyl derivative of BCECF; PCT, proximal convoluted tubule; SITS, 4-acetamido-4'-isothiocyanostilbene-2,2'-disulfonate. 
Table I. Perfusion Solutions

\begin{tabular}{|c|c|c|c|c|c|c|c|c|}
\hline Solution & 1 & 2 & 3 & 4 & 5 & 6 & 7 & 8 \\
\hline & & \multicolumn{7}{|c|}{$\mathrm{mmol} / \mathrm{liter}$} \\
\hline $\mathrm{Na}^{+}$ & 147 & 0 & 147 & 0 & 147 & 139.9 & 129 & 129 \\
\hline $\mathbf{K}^{+}$ & 5 & 5 & 5 & 5 & 5 & 5 & 5 & 5 \\
\hline $\mathrm{Mg}^{2+}$ & 1 & 1 & 1 & 1 & 1 & 1 & 1. & 1 \\
\hline $\mathrm{Ca}^{2+}$ & 9.4 & 9.4 & 9.4 & 9.4 & 9.4 & 9.4 & 9.4 & 9.4 \\
\hline Cholin ${ }^{+}$ & & 25 & & & & & & \\
\hline $\mathrm{NH}_{4}^{+}$ & & & & & & & & 20 \\
\hline $\mathrm{NMG}^{+}$ & & 120 & & 145 & & & 20 & \\
\hline $\mathrm{Cl}^{-}$ & 0 & 0 & 0 & 0 & 0 & 0 & 0 & 0 \\
\hline $\mathrm{HCO}_{3}^{-}$ & 25 & 25 & 0 & 0 & 5 & 0 & 25 & 25 \\
\hline $\mathrm{HPO}_{4}^{-}$ & 1 & 1 & 1 & 1 & 1 & 1 & 1 & 1 \\
\hline $\mathrm{SO}_{4}^{-}$ & 1 & 1 & 1 & 1 & 1 & 1 & 1 & 1 \\
\hline Hepes- & 13.8 & 13.8 & 13.8 & 13.8 & 6.7 & 6.7 & 13.8 & 13.8 \\
\hline Gluconate $^{-}$ & 120.6 & 120.6 & 145.6 & 143.6 & 147.7 & 147.7 & 122.6 & 122.6 \\
\hline Glucose & 5 & 5 & 5 & 5 & 5 & 5 & 5 & 5 \\
\hline Alanine & 5 & 5 & 5 & 5 & 5 & 5 & 5 & 5 \\
\hline Urea & 5 & 5 & 5 & 5 & 5 & 5 & 5 & 5 \\
\hline Hepes & 11.2 & 11.2 & 11.2 & 11.2 & 18.3 & 18.3 & 11.2 & 11.2 \\
\hline $\mathrm{CO}_{2}(\%)$ & 7 & 7 & 0 & 0 & 7 & 0 & 7 & 7 \\
\hline $\mathrm{O}_{2}(\%)$ & 93 & 93 & 100 & 100 & 93 & 100 & 93 & 93 \\
\hline $\mathrm{pH}$ & 7.4 & 7.4 & 7.4 & 7.4 & 6.8 & 6.8 & 7.4 & 7.4 \\
\hline
\end{tabular}

the PCT of midcortical nephrons were used. Segments where attachment to a glomerulus was identified ( $\times 60$ magnification) were not used. Preliminary studies had shown that the interanimal variability of the rates of the luminal $\mathrm{Na} / \mathrm{H}$ antiporter and the basolateral $\mathrm{Na} /\left(\mathrm{HCO}_{3}\right)_{3}$ cotransporter could be minimized when dissection was restricted to this nephron segment. One tubule per animal was studied. The tubules were transferred to a bath chamber with a volume of about $150 \mu \mathrm{l}$ and hooked up to a microperfusion setup as previously described $(8,12)$. The bath fluid flow rate was $30 \mathrm{ml} / \mathrm{min}$, driven by hydrostatic pressure. With this setup, $>95 \%$ of the fluorescence signal was achieved within $0.5 \mathrm{~s}$ after changing bath fluid from a control solution to one containing $0.5 \mathrm{mM} \mathrm{5,6-carboxyfluorescein.} \mathrm{Bath} \mathrm{pH}$ was monitored continuously by placing a commercial, flexible $\mathrm{pH}$ electrode into the bath (MI 21960, Microelectrodes Inc., Londonderry, $\mathrm{NH})$. The bath solutions were prewarmed to $38^{\circ} \mathrm{C}$ and equilibrated with the appropriate gasses (Table I). Bath temperature was maintained at $38 \pm 0.5^{\circ} \mathrm{C}$. Luminal perfusate flow was $2.5 \mathrm{ml} / \mathrm{min}$ driven by gas pressure with the efflux valve constantly open. $>95 \%$ of the fluorescence signal was obtained within about $0.4 \mathrm{~s}$ after changing luminal fluids from a control solution to one containing $0.5 \mathrm{mM} \mathrm{5,6-carboxy-}$ fluorescein.

To minimize motion, the distal end of the tubule was sucked gently into a collection pipette. In addition, the average tubule length exposed to the bath fluids was limited to about $350 \mu \mathrm{m}$. The tubules were allowed to equilibrate at $38^{\circ} \mathrm{C}$ for $10 \mathrm{~min}$ during which they were loaded with the acetoxymethyl derivative of $\left(2^{\prime \prime}, 7^{\prime}\right)$-bis-(carboxyethyl)$(5,6)$-carboxyfluorescein (BCECF), BCECF-AM (Molecular Probes, Eugene, OR), from the bath in a concentration of $10 \mu \mathrm{M}$.

The perfusion solutions used in this study are listed in Table $I$. $\mathrm{CO}_{2} / \mathrm{HCO}_{3}$-free solutions were bubbled with $100 \% \mathrm{O}_{2}$ passed through $3 \mathrm{~N} \mathrm{KCN}$ as a base trap. With these precautions bath total $\mathrm{CO}_{2}$ is zero (12). 4-Acetamido-4'-isothiocyanostilbene-2,2'-disulfonate (SITS) was obtained from International Chemical and Nuclear (Cleveland, $\mathrm{OH}$ ). Amiloride, nigericin, valinomycin, and all solution salts were purchased from Sigma Chemical Co. (St. Louis, MO).

Analysis. Measurements were made with an inverted fluorescent microscope (Fluovert, Leitz, Wetzlar, Federal Republic of Germany) using a $\times 25$ objective as previously described $(8,12,13)$.

Fluorescence was measured, as previously described $(8,12,13,14)$ alternately at 500- and 450-nm excitation and at an emission wave- length of $530 \mathrm{~nm}$ (interference filters, Corion Corp., Holliston, MA). Fluorescence was not affected by addition of $1 \mathrm{mM}$ amiloride to the luminal perfusate (peak excitation/emission: $364 / 418 \mathrm{~nm}$ ) or $1 \mathrm{mM}$ SITS to the bath perfusate (peak excitation/emission:348/416 nm [13]).

The initial changes in cell pH $\left(\mathrm{dpH}_{\mathrm{i}} / \mathrm{d} t\right)$ in response to an experimental maneuver were determined as described in detail previously $(12,13)$. The analysis was performed in a blinded manner by two persons who did not know whether the tracing originated from a normal or an acidotic rabbit. In order to relate the fluorescence excitation ratio to cell $\mathrm{pH}$, the tubules were calibrated individually at the end of each experiment. This approach was chosen because intertubular variability in the slope of the calibration curve could introduce major errors in the calculations of the acidification rate and steady state cell pH values. Because previous studies by us and others have shown that the intracellular calibration curve is linear (12-14), the tubules were calibrated at two different extracellular $\mathrm{pH}$ values (usually 7.3 and 6.7) using well-buffered solutions ( $25 \mathrm{mM}$ HEPES, $33 \mathrm{mM}$ phosphate) containing nigericin (a $\mathrm{K} / \mathrm{H}$ antiporter, $7 \mu \mathrm{M})$, valinomycin $(5 \mu \mathrm{m})$, and $66 \mathrm{mM}$ potassium. Both lumen and bath were perfused with the calibration solutions.

The rates of initial cell acidification and the mean changes in cell $\mathrm{pH}$ represent the means of the values obtained by changing to the experimental solution and the values obtained by changing back to the control solution.

For the measurement of luminal $\mathrm{pH}$, tubules were perfused at 10 $\mathrm{nl} / \mathrm{min}$ with the poorly permeable BCECF-salt $(20 \mu \mathrm{M})$ and fluorescence was recorded at 500 - and $450-\mathrm{nm}$ wavelengths. The measuring diaphragm was placed over the tubule lumen and opened over a length of four to five cells at the beginning and the end of the perfused segment. Background fluorescence was determined before and after perfusing the tubule with the dye. Since background after the experiment was about $50 \%$ higher, the mean of the two background values was used for analysis. The signal/background ratio was $>20: 1$ at 500 $\mathrm{nm}$ and $>17: 1$ at $450 \mathrm{~nm}$ at the end of all experiments. The dye was calibrated in a glass capillary at $\mathrm{pH} 6.7,7.0,7.3$, and 7.6. The luminal flow rate was controlled by a nanoliter infusion pump (Harvard Apparatus Co., Inc. South Natick, MA), which was calibrated using tritiated inulin. The tubule length was measured at the end of the experiment through the microscope eyepiece. The luminal $\mathrm{pH}$ value at $1 \mathrm{~mm}$ of perfused tubule was interpolated from the initial and end-tubular luminal $\mathrm{pH}$ and the known overall tubule length. The mean tubule length was $1.1 \pm 0.1 \mathrm{~mm}$ in both groups.

Statistics. The data were analyzed using Student's $t$ test for unpaired data. The calibration data were fit using linear regression. Results are reported as mean \pm standard error of the mean.

\section{Results}

Adaptation to chronic respiratory acidosis. Table II shows the principal blood parameters from acidotic and control rabbits. Blood pH was significantly lower in acidotic animals than in controls: $7.28 \pm 0.01$ vs. $7.43 \pm 0.01$. Arterial $\mathrm{PCO}_{2}$ and $\mathrm{HCO}_{3}$ were significantly higher in acidotic animals than in controls: $69.0 \pm 1.2$ vs. $40.4 \pm 1.1$ torr and $32.6 \pm 0.7$ vs. $26.1 \pm 0.4 \mathrm{mM}$, respectively. Chloride was lower in acidotic rabbits: $96.1 \pm 0.9$ vs. $100.8 \pm 1.1 \mathrm{mM}$. In both groups, renal function, as assessed by determination of blood urea nitrogen and creatinine, was normal. There was no significant change in the anion gap in either group. Urine $\mathrm{pH}$ was $7.5 \pm 0.5$ in normals and $6.5 \pm 0.5(P$ $<0.002$ ) in acidotic rabbits. Urine samples from both groups were uniformly negative for ketones, glucose, protein, and leukocytes.

Luminal acidification in tubules from normal and acidotic rabbits. To determine whether acidification was indeed stimulated in $\mathrm{S}_{2}$ segments of the rabbit kidney, luminal $\mathrm{pH}$ was 
Table II. Principal Blood Parameters in Control and Respiratory Acidosis

\begin{tabular}{lcccccccc}
\hline & $\mathrm{PCO}_{2}$ & $\mathrm{HCO}$ & $\mathrm{pH}$ & $\mathrm{Cl}^{-}$ & $\mathrm{Na}^{+}$ & $\mathrm{K}^{+}$ & $\mathrm{BUN}$ & $\mathrm{Creatinine}$ \\
\hline & torr & $m M$ & $U$ & $m M$ & $m M$ & $m M$ & $m g / d l$ & $m g / d l$ \\
Acidosis & $69.0 \pm 1.2$ & $32.6 \pm 0.7$ & $7.28 \pm 0.01$ & $96.1 \pm 0.9$ & $141.9 \pm 0.6$ & $4.9 \pm 0.1$ & $17.5 \pm 1.5$ & $0.77 \pm 0.05$ \\
Control & $40.4 \pm 1.1$ & $26.1 \pm 0.4$ & $7.43 \pm 0.01$ & $100.8 \pm 1.1$ & $141.0 \pm 0.9$ & $5.0 \pm 0.2$ & $16.0 \pm 3.2$ & $0.73 \pm 0.08$ \\
$P$ & $<0.001$ & $<0.001$ & $<0.001$ & $<0.005$ & $\mathrm{NS}^{*}$ & $\mathrm{NS}^{*}$ & $\mathrm{NS}^{*}$ & $\mathrm{NS}^{*}$ \\
\hline
\end{tabular}

Mean \pm SEM. NS*, not significant.

measured at the beginning and the end of perfused tubules from normal and acidotic rabbits. Bath and lumen were perfused with solution 1 (Table I), from which Hepes had been eliminated. Since ambient $\mathrm{PCO}_{2}$ and luminal flow rate were held constant, an increase in the rate of luminal acidification would lower luminal pH more over a given distance. Table III shows that luminal pH (after $1 \mathrm{~mm}$ of perfused length) in tubules from acidotic rabbits $(n=6)$ was significantly lower than in tubules from normal animals ( $n=5,7.03 \pm 0.09$ vs. $7.26 \pm 0.06, P<0.005$ ). Since baseline cell $\mathrm{pH}$ values and cellular buffer capacities were the same in tubules from acidotic and normal rabbits (see below), it can be assumed that this increase in luminal acidification was accompanied by a similar increase in basolateral bicarbonate exit. Thus, it can be concluded from these studies that bicarbonate reabsorption is stimulated in $S_{2}$ segments of the rabbit PCT in response to chronic respiratory acidosis.

Effects of luminal and bath sodium removal. These experiments were designed to analyze and compare the rates of the luminal $\mathrm{Na} / \mathrm{H}$ antiporter and the basolateral $\mathrm{Na} /\left(\mathrm{HCO}_{3}\right)_{3} \mathrm{Co}-$ transporter in the same tubule either from normal or acidotic animals.

When chloride is removed from luminal and bath perfusates in the rabbit PCT, changes in luminal sodium concentration can be expected to affect cell $\mathrm{pH}$ by changing the rate of the luminal $\mathrm{Na} / \mathrm{H}$ antiporter. For the analysis of the luminal $\mathrm{Na} / \mathrm{H}$ antiporter by luminal sodium removal, the solutions were $\mathrm{HCO}_{3}$-free, containing $\mathrm{Hepes}$ and $0.1 \mathrm{mM}$ acetazolamide in luminal and bath perfusates (solutions 3 and 4, Table I). Previous studies have shown that analysis of luminal transporters is facilitated by effectively blocking the rate of the basolateral transporters, because these latter transporters are more important determinants of cell $\mathrm{pH}(8,15)$. We have also demonstrated that the $\mathrm{Na} /\left(\mathrm{HCO}_{3}\right)_{3}$ cotransporter is fully inhibited in the absence of exogenous $\mathrm{CO}_{2} / \mathrm{HCO}_{3}$ and $0.1 \mathrm{mM}$ acetazolamide and that acetazolamide does not affect the rate of the $\mathrm{Na} / \mathrm{H}$ antiporter in this setting (12).

Table III. Luminal pH in Tubules from Control and Acidotic Rabbits

\begin{tabular}{lccr}
\hline & $\mathrm{pH}_{\text {initial }}$ & $\mathrm{pH}_{\mathbf{1 m m}}$ & $n$ \\
\hline Control & $7.38 \pm 0.04$ & $7.26 \pm 0.06$ & 5 \\
Acidosis & $7.41 \pm 0.05$ & $7.03 \pm 0.09$ & 6 \\
$P$ value & $\mathrm{NS}$ & $<0.005$ &
\end{tabular}

$\mathrm{pH}_{\text {initial }}$ denotes luminal $\mathrm{pH}$ at beginning of perfused segments; $\mathrm{pH}_{1 \mathrm{~mm}}$ denotes luminal $\mathrm{pH}$ after $1 \mathrm{~mm}$ of the perfused segments.
Fig. 1. (left two bars) illustrates that the initial rate of cell acidification in response to luminal sodium removal was about $63 \%$ higher in chronic respiratory acidosis compared to control: $3.87 \pm 0.37 \mathrm{pH} \mathrm{U} / \mathrm{min}(n=12)$ in tubules from acidotic animals versus $2.38 \pm 0.19 \mathrm{pH} \mathrm{U} / \mathrm{min}(n=11)$ in tubules from normal animals $(P<0.005)$. Luminal sodium removal acidified the cells at steady state by a mean of $0.62 \pm 0.05 \mathrm{pH} \mathrm{U}$ from $7.38 \pm 0.04$ to $6.74 \pm 0.05$ with recovery to $7.36 \pm 0.03 \mathrm{pH}$ $\mathrm{U}$ upon readdition of luminal sodium. Cells in tubules from acidotic rabbits acidified by a mean of $0.63 \pm 0.06 \mathrm{pH} \mathrm{U}$ from $7.39 \pm$ to $6.74 \pm 0.06$ with recovery to $7.35 \pm 0.02 \mathrm{pH} U$ when luminal sodium was readded. Thus, in contrast to the marked difference in their initial rates, tubules from normal and acidotic animals did not differ significantly in steady-state cell pH values nor in the mean change of cell acidification induced by luminal sodium removal.

In the absence of chloride, changes in bath sodium will affect cell $\mathrm{pH}$ by changing the rate of the basolateral $\mathrm{Na} /\left(\mathrm{HCO}_{3}\right)_{3}$ cotransporter. To analyze this transporter, tubules were perfused without chloride in the presence of $\mathrm{HCO}_{3}$ at $\mathrm{pH} 7.4$ in the control period. In the experimental period bath sodium was removed (solutions 1 and 2, Table I). When bath sodium was removed in the same tubules steady-state pH values were again not different: $7.36 \pm 0.03$ in normal and $7.40 \pm 0.03 \mathrm{pH} U$ in acidotic rabbits. The mean change in cell $\mathrm{pH}$ induced by bath sodium removal was $0.57 \pm 0.06$ in normal and $0.62 \pm 0.08$ in acidotic animals (NS).

Fig. 1 (right two bars) shows, however, that the initial acidification rate induced by bath sodium removal differed signifi-

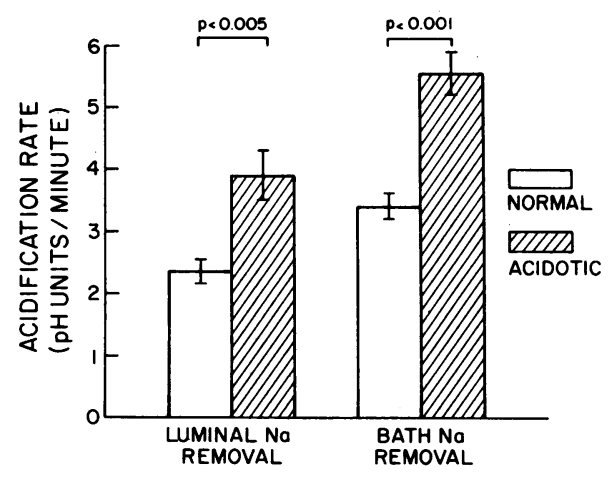

Figure 1. Effect of luminal (left two bars) and peritubular (right two bars) sodium removal on the initial rate of cell acidification $\left(\mathrm{dpH}_{\mathrm{i}} /\right.$ $\mathrm{d} t$ ). (Open bars) results from normal $(n=11)$; (hatched bars) results from acidotic rabbits $(n=12)$. The effects of peritubular and luminal sodium removal were examined in the same tubule. The acidification rate induced by both luminal and peritubular sodium removal is significantly increased by about $60 \%$ in tubules harvested from animals with chronic respiratory acidosis. 
cantly: the cells acidified by $3.39 \pm 0.2 \mathrm{pH} \mathrm{U} / \mathrm{min}$ in tubules from control and by $5.54 \pm 0.35 \mathrm{pH} \mathrm{U} / \mathrm{min}$ in tubules from acidotic animals $(P<0.001)$. Thus, chronic respiratory acidosis stimulated the rate of the $\mathrm{Na} /\left(\mathrm{HCO}_{3}\right)_{3}$ cotransporter by about $63 \%$.

These studies show that tubules from normal and acidotic rabbits when perfused with artificial solutions at $\mathrm{pH} 7.4$ had the same steady-state cell pH. Chronic respiratory acidosis induced a marked parallel stimulation of about $60 \%$ in the rates of the luminal $\mathrm{Na} / \mathrm{H}$ antiporter and the basolateral $\mathrm{Na} /\left(\mathrm{HCO}_{3}\right)_{3}$ cotransporter although the steady-state cell $\mathrm{pH}$ changes were similar.

The results of these studies were independent of the time sequence of analysis of the effect of luminal or bath sodium removal. Fig. 2 shows original tracings of bath and luminal sodium removal in a tubule from a normal (top) and an acidotic animal (bottom).

Effect of lowering luminal $\mathrm{pH}$. The next study compared the effects of lowering luminal $\mathrm{pH}$ on cell acidification in control and acidotic rabbits. In the absence of exogenous $\mathrm{CO}_{2}$ / $\mathrm{HCO}_{3}$ and with $0.1 \mathrm{mM}$ acetazolamide added to luminal and bath perfusates luminal $\mathrm{pH}$ was lowered from 7.4 in the control period to 6.8 in the experimental period (solutions 3 and 6, Table I). Again, the studies were performed in the absence of chloride. Since a change in luminal $\mathrm{pH}$ is a less specific indicator of the $\mathrm{Na} / \mathrm{H}$ antiporter activity than sodium removal, the studies were performed in the absence and presence of $1 \mathrm{mM}$ luminal amiloride. Lowering luminal $\mathrm{pH}$ acidified cells in
PCT from normal rabbits at an initial rate of $2.76 \pm 0.24 \mathrm{pH}$ $\mathrm{U} / \mathrm{min}$, whereas cells in PCT from acidotic rabbits acidified by $4.67 \pm 0.15 \mathrm{pH} \mathrm{U} / \mathrm{min}$ ( $n=6$ in each series, $P<0.001)$. In the presence of $1 \mathrm{mM}$ luminal amiloride the initial rate of acidification induced by lowering luminal $\mathrm{pH}$ was $0.81 \pm 0.1 \mathrm{pH}$ $\mathrm{U} / \mathrm{min}$ in PCT from normal rabbits and was the same in PCT from acidotic rabbits, $0.89 \pm 0.1 \mathrm{pH} \mathrm{U} / \mathrm{min}$. Therefore, expression of the results as amiloride-sensitive rate of cell acidification reflects $\mathrm{Na} / \mathrm{H}$ antiporter activity most accurately. Fig. 3 shows that the amiloride-inhibitable fraction of PCT cell acidification was stimulated by about $69 \%$ in PCT from animals with chronic respiratory acidosis.

Again, the steady-state cell $\mathrm{pH}$ values in the two groups were not different: $7.29 \pm 0.03$ in PCT from normal rabbits and $7.32 \pm 0.06$ in PCT from acidotic rabbits (NS). The mean change in cell $\mathrm{pH}$ induced by lowering luminal $\mathrm{pH}$ was $0.51 \pm 0.05$ and $0.59 \pm 0.09$, respectively (NS).

Effect of lowering bath $\mathrm{pH}$. The next set of experiments examined the effects of lowering bath $\mathrm{pH}$ in the absence of chloride on cell acidification in PCT from control and acidotic animals. Tubules were perfused symmetrically with $25 \mathrm{mM}$ $\mathrm{HCO}_{3}$ in the control period. Bath $\mathrm{HCO}_{3}$ was lowered to $5 \mathrm{mM}$ in the experimental period with $\mathrm{PCO}_{2}$ held constant at 40 torr (bath pH change from 7.4 to 6.8 , solutions 1 and 5, Table I). The experiments were performed both in the absence and presence of $1 \mathrm{mM}$ bath SITS, an inhibitor of the basolateral $\mathrm{Na} /\left(\mathrm{HCO}_{3}\right)_{3}$ cotransporter.

The initial rate of cell acidification induced by lowering

$$
\text { CONTROL: } \mathrm{P}_{\mathrm{CO}_{2}}=40.8, \mathrm{pH}=7.42
$$

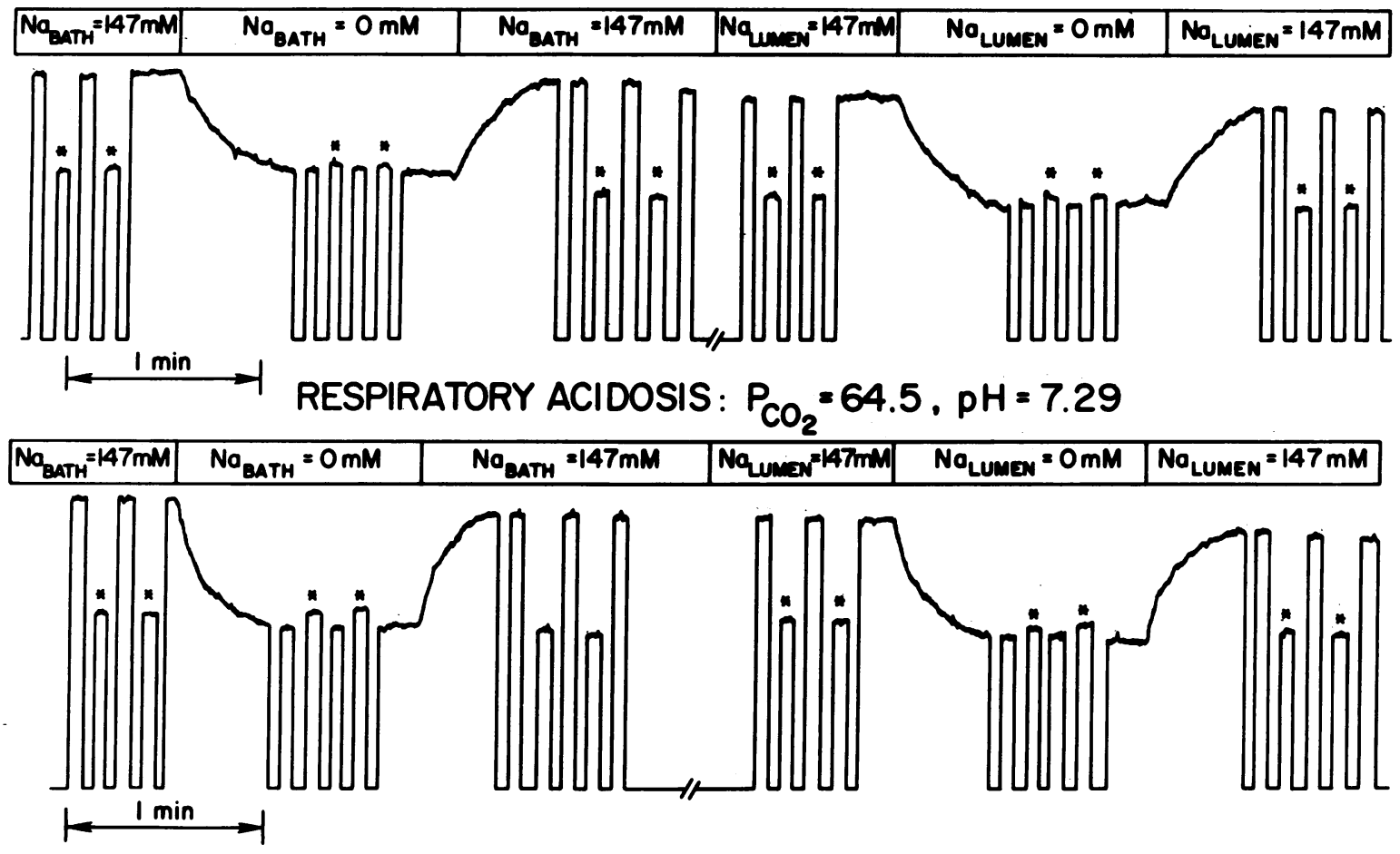

Figure 2. Effects of bath (left two tracings) and luminal (right two tracings) sodium removal in a tubule from a control (top two tracings) and an acidotic (bottom two tracings) rabbit: typical study. Fluorescence measurements at 450 -nm wavelength (pH-insensitive) are marked by asterisks, while all other bars and the transients are recordings at $500-\mathrm{nm}$ wavelength (pH-sensitive). A decrease in 500-nm fluorescence represents cell acidification. The initial rate of change in $500-\mathrm{nm}$ fluorescence is enhanced in the tubule from the acidotic animal (bottom) both in response to bath and luminal sodium removal. 


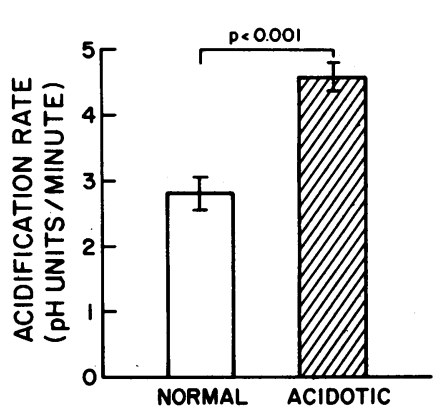

bath $\mathrm{HCO}_{3}$ differed again significantly: $2.87 \pm 0.28 \mathrm{pH} \mathrm{U} / \mathrm{min}$ in PCT from control $(n=6)$, but $4.96 \pm 0.3 \mathrm{pH} \mathrm{U} / \mathrm{min}$ in PCT from acidotic animals $(n=7, P<0.001)$. Addition of $1 \mathrm{mM}$ bath SITS similarly inhibited the rate of cell acidification to $0.48 \pm 0.08 \mathrm{pH} \mathrm{U} / \mathrm{min}$ in PCT from acidotic rabbits and to $0.47 \pm 0.14 \mathrm{pH} \mathrm{U} / \mathrm{min}$ in PCT from controls (NS). Fig. 4 shows the SITS-inhibitable fraction of the initial rate of cell acidification induced by lowering bath $\mathrm{HCO}_{3}$ concentration in PCT from control and acidotic rabbits and illustrates that the rate of the basolateral $\mathrm{Na} /\left(\mathrm{HCO}_{3}\right)_{3}$ cotransporter was stimulated by about $73 \%$ in chronic respiratory acidosis. A comparison with Fig. 3 shows that chronic respiratory acidosis induced a comparable stimulation of about $70 \%$ each in the rates of the luminal $\mathrm{Na} / \mathrm{H}$ antiporter and the basolateral $\mathrm{Na} /\left(\mathrm{HCO}_{3}\right)_{3}$ cotransporter when these transporters were analyzed by the same change in ambient $\mathrm{pH}$.

Steady-state cell $\mathrm{pH}$ values were again not significantly different in PCT from normal $(7.41 \pm 0.04)$ and acidotic (7.39 \pm 0.02$)$ animals. Similarly, lowering bath $\mathrm{HCO}_{3}$ concen-

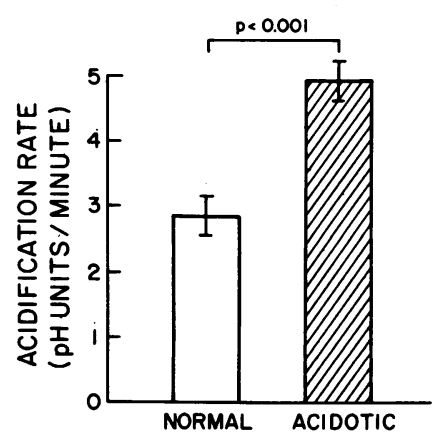

Figure 4. Effect of lowering peritubular $\mathrm{pH}$ from 7.4 to 6.8 on the initial rate of cell acidification in tubules from normal (open bar) and acidotic (hatched bar) rabbits. Peritubular bicarbonate was lowered from 25 to $5 \mathrm{mM}$ at a constant $\mathrm{PCO}_{2}$ of 40 torr. The rates given represent the difference in acidification rates in the absence and presence of $1 \mathrm{mM}$ bath SITS (e.g., the SITS-inhibitable cell acidification rate). The cell acidification rate is stimulated by $73 \%$ in tubules from acidotic animals. Six tubules from normal and seven tubules from acidotic animals were studied. tration induced the same mean change in cell $\mathrm{pH}$ in control and acidotic animals: $0.51 \pm 0.03 \mathrm{pH} \mathrm{U}$ and $0.52 \pm 0.04 \mathrm{pH} \mathrm{U}$, respectively (NS).

Determination of buffer capacity. The rate of initial acidification $\left(\mathrm{dpH}_{\mathrm{i}} / \mathrm{d} t\right)$ induced by the experimental maneuvers is given by $\mathrm{dpH}_{\mathrm{i}} / \mathrm{d} t=\left(J_{\mathrm{H}}\right) /(B \cdot V / \mathrm{mm})$, where $J_{\mathrm{H}}$ is the proton flux, $B$ is the buffer capacity, and $V / \mathrm{mm}$ the tubule volume per millimeter length. The inner and outer tubule diameters (measured with $\times 250$ magnification) did not differ between normal and acidotic rabbits. Therefore, differences in the acidification rate between acidotic and normal rabbits could be secondary to differences in the cellular buffer capacities and not reflect any changes in the transporter rates. The buffer capacity was determined in tubules from control and acidotic rabbits using the rapid $\mathrm{NH}_{3}$ washout technique (16). Tubules were perfused in the bilateral absence of chloride at $\mathrm{pH} 7.4$ and $\mathrm{NH}_{3} / \mathrm{NH}_{4}$ was added to the bath (solution 7 lumen and solution 8 bath, Table I). $\mathrm{NH}_{3} / \mathrm{NH}_{4}$ was rapidly removed from the bath (solution 8 replaced by solution 7, Table I) and buffer capacity was then determined as previously described (12). Because an accurate determination of buffer capacity requires that acid extrusion processes be blocked, these experiments were performed in the presence of $1 \mathrm{mM}$ luminal amiloride (to block the $\mathrm{Na} / \mathrm{H}$ antiporter) and $1 \mathrm{mM}$ bath SITS (to block the $\mathrm{Na} /\left(\mathrm{HCO}_{3}\right)_{3}$ cotransporter). As illustrated by Table IV the buffer capacities were similar in tubules from normal and acidotic rabbits: $67 \pm 12$ and $71 \pm 16 \mathrm{mmol} / \mathrm{pH} \mathrm{U}$, respectively $(n$ $=8$ in each group, NS). Thus, the differences in acidification rate cannot be accounted for by differences in buffer capacity.

\section{Discussion}

The luminal $\mathrm{Na} / \mathrm{H}$ antiporter and the basolateral $\mathrm{Na} /\left(\mathrm{HCO}_{3}\right)_{3}$ cotransporter are the most important determinants of both transcellular bicarbonate reabsorption and cell $\mathrm{pH}$ defense against acute changes in ambient $\mathrm{PCO}_{2}$. The present studies examined whether proximal acidification in the rabbit is stimulated in response to chronic respiratory acidosis and whether this stimulation involves adaptive changes of these transporters. The key findings were: (a) tubules from acidotic rabbits have a significantly lower luminal $\mathrm{pH}$ after $1 \mathrm{~mm}$ of perfused length consistent with an increase in luminal acidification and bicarbonate reabsorption (Table III); $(b)$ the initial rate of cell acidification $\left(\mathrm{dpH}_{\mathrm{i}} / \mathrm{d} t\right)$ in response to luminal and peritubular sodium removal (examined in the same tubule) was increased by about $60 \%$, respectively, in tubules from animals with chronic respiratory acidosis (Figs. 1 and 2); (c) lowering luminal or peritubular $\mathrm{pH}$ induced an initial rate of cell acidification that was enhanced by about $70 \%$ each in tubules from animals with chronic respiratory acidosis (Figs. 3 and 4); (d) the intracellular buffer capacity (determined by the $\mathrm{NH}_{3}$ /

Table IV. Buffer Capacity

$m m o l / p H U$

$\begin{array}{lc}\text { Normal } & 67 \pm 12 \\ \text { Acidotic } & 71 \pm 16 \\ P & \mathrm{NS}^{*}\end{array}$

Mean \pm SEM. NS*, nonsignificant. $n=8$ tubules in each series. 
$\mathrm{NH}_{4}$ washout technique) was the same in tubules from acidotic and control rabbits (Table IV), and (e) steady-state cell pH and the mean changes in cell $\mathrm{pH}$ in tubules from control and acidotic animals were not significantly different. These results show that the rates of the luminal $\mathrm{Na} / \mathrm{H}$ antiporter and the basolateral $\mathrm{Na} /\left(\mathrm{HCO}_{3}\right)_{3}$ cotransporter increase in parallel during chronic respiratory acidosis.

The buffer capacity and the steady-state cell $\mathrm{pH}$ values were not different in tubules from acidotic and normal animals, indicating that the observed increases in cell acidification in tubules from acidotic rabbits were not due to altered driving forces, but rather to changed intrinsic properties of the transporters. Because these studies were performed at $\mathrm{pH} 7.4$ and a $\mathrm{PCO}_{2}$ of 40 , it is difficult to predict whether the in vivo cell $\mathrm{pH}$ values in PCT in normal and acidotic rabbits would also be the same, because they are determined by the relative importance of ambient $\mathrm{pH}$, bicarbonate concentration and $\mathrm{PCO}_{2}$ in the regulation of cell $\mathrm{pH}$. However, studies in rat proximal tubules (17) and NMR measurements of renal cell pH (18) suggest that chronic respiratory acidosis does not affect cell $\mathrm{pH}$ in vivo.

The experiments were designed to specifically test the properties of the luminal $\mathrm{Na} / \mathrm{H}$ antiporter and the basolateral $\mathrm{Na} /\left(\mathrm{HCO}_{3}\right)_{3}$ cotransporter: all experiments were performed in the absence of chloride thus eliminating luminal and basolateral chloride-coupled base transporters. In addition, the $\mathrm{pH}$ effect on cell acidification was analyzed in the presence and absence of amiloride (inhibitor of the luminal $\mathrm{Na} / \mathrm{H}$ antiporter) or SITS (inhibitor of the basolateral $\mathrm{Na} /\left(\mathrm{HCO}_{3}\right)_{3}$ cotransporter). Therefore, contributions of the putative luminal $\mathrm{H}$-ATPase and other basolateral $\mathrm{H} / \mathrm{OH} / \mathrm{HCO}_{3}$ transporters to the observed changes can be excluded.

The degree of the intrinsic tubular response to the initial phase of chronic hypercapnia and the relative importance of the proximal and distal nephron in increasing plasma bicarbonate is still a matter of considerable debate (see Cogan [19] for comprehensive review). It is clear, however, that the hyperbicarbonatemia of the chronic phase is sustained by increased renal hydrogen secretion (19-30). This study and data from the rat (1) indicate that this process is mediated, in great part, by an increase in the intrinsic rate of bicarbonate reabsorption by the proximal tubule. The effect of hypercapnia on bicarbonate reabsorption seems specific because it is independent of sodium intake (24), bicarbonate availability and rate of net acid excretion (25), potassium stores (31), mineralocorticoid activity (23), or oxygen tension (27). The present studies establish the cellular mechanism of the increased bicarbonate reabsorption in the proximal tubule in response to chronic respiratory acidosis: adaptation to chronic respiratory acidosis involves stimulation of the luminal $\mathrm{Na} / \mathrm{H}$ antiporter and the basolateral $\mathrm{Na} /\left(\mathrm{HCO}_{3}\right)_{3}$ cotransporter. They agree with studies using brush border membrane vesicles from rabbit renal cortex which have found an increase in $\mathrm{Na} / \mathrm{H}$ antiporter activity induced by chronic respiratory acidosis $(9,32)$.

For a sustained increase of transcellular bicarbonate reabsorption to occur, the increased rate of the luminal proton secretion has to be accompanied by a similar degree of increase in the rate of the basolateral bicarbonate exit in the steady state. The present studies show that chronic respiratory acidosis induced a parallel increase in transporter rates. Both the luminal $\mathrm{Na} / \mathrm{H}$ antiporter and the basolateral $\mathrm{Na} /\left(\mathrm{HCO}_{3}\right)_{3} \mathrm{CO}-$ transporter increased their rates by about $60 \%$ in response to ambient sodium removal (Figs. 1 and 2 analyzed in the same tubule) and by about $70 \%$ in response to lowering ambient $\mathrm{pH}$ (Figs. 3 and 4, analyzed in different tubules). A similar parallel adaptation of these two transporters has been described in metabolic acid-base disturbances $(33,34)$. The findings of the present studies are important physiologically because chronic respiratory acidosis is the only acid-base disorder in which there is unequivocal agreement based on this and other studies $(1,19)$ that an increase in absolute proximal bicarbonate transport occurs. This stimulation might require an increase in transporter rates.

In conclusion, chronic respiratory acidosis leads to a parallel adaptation in the rates of the luminal $\mathrm{Na} / \mathrm{H}$ antiporter and the basolateral $\mathrm{Na} /\left(\mathrm{HCO}_{3}\right)_{3}$ cotransporter. These in vivo adaptive changes can be demonstrated in the isolated, intact tubule perfused with artificial solutions in vitro. The quantitatively similar increase in the rate of the luminal $\mathrm{Na} / \mathrm{H}$ antiporter and the basolateral $\mathrm{Na} /\left(\mathrm{HCO}_{3}\right)_{3}$ cotransporter may mediate the enhanced proximal bicarbonate reabsorption in chronic respiratory acidosis.

\section{Acknowledgments}

The author thanks Drs. Floyd C. Rector, Jr., M. G. Cogan, and C. A. Berry for their support and advice and Drs. C. A. Berry and F.-Y. Liu for help in data analysis. He also acknowledges the technical assistance of Mr. John Lowe and the secretarial help of Mrs. Gracie Bernacki.

This study was supported from grants DK-27045 and DK-26142 of the National Institutes of Health. Dr. Krapf is the recipient of a generous grant from the Swiss Foundation for Biologic and Medical Grants.

\section{References}

1. Cogan, M. G. 1984. Chronic hypercapnia stimulates proximal bicarbonate reabsorption in the rat. J. Clin. Invest. 74:1942-1947.

2. Burg, M. B., and N. Green. 1977. Bicarbonate transport by isolated perfused rabbit proximal convoluted tubules. Am. J. Physiol. 233 (Renal Fluid Electrolyte Physiol. 2):F307-F314.

3. McKinney, T. D., and M. B. Burg. 1977. Bicarbonate and fluid absorption by renal proximal straight tubules. Kidney Int. 12:1-8.

4. Chan, Y. L., and G. Giebisch. 1981. Relationship between sodium and bicarbonate transport in the rat proximal convoluted tubule. Am. J. Physiol. 240(Renal Fluid Electrolyte Physiol. 14):F622-F633.

5. Chantrelle, B. M., M. G. Cogan, and F. C. Rector, Jr. 1982. Evidence for coupled sodium/hydrogen exchange in the rat superficial proximal convoluted tubule. Pfluegers Arch. Eur. J. Physiol. 395:186189.

6. Ullrich, K. J., G. Rumrich, and K. Baumann. 1975. Renal proximal tubular buffer-(glycodiazine) transport. Pfluegers Arch. Eur. J. Physiol. 357:149-163.

7. Sasaki, S., and C. A. Berry. 1984. Mechanism of bicarbonate exit across basolateral membrane of the rabbit proximal convoluted tubule. Am. J. Physiol. 246 (Renal Fluid Electrolyte Physiol. 15):F889-F896.

8. Krapf, R., C. A. Berry, R. J. Alpern, and F. C. Rector, Jr. 1988. Regulation of cell pH by ambient $\mathrm{PCO}_{2}$, bicarbonate and $\mathrm{pH}$ in the rabbit proximal tubule. J. Clin. Invest. 81:381-389.

9. Talor, Z., W.-Ch. Yang, J. Shuffield, E. Sack, and J. A. L. Arruda. 1987. Chronic hypercapnia enhances $V_{\max }$ of $\mathrm{Na}-\mathrm{H}$ antiporter of renal brush-border membranes. Am. J. Physiol. 253 (Renal Fluid Electrolyte Physiol. 22):F394-F400.

10. Northrup, T. E., S. Garella, E. Perticucci, and J. J. Cohen. 1988. Acidemia alone does not stimulate rat renal $\mathrm{Na} / \mathrm{H}$ antiporter activity. Am. J. Physiol. 255 (Renal Fluid Electrolyte Physiol. 24):F237-F243.

11. Zeidel, M. L., and J. L. Seifter. 1988. Regulation of $\mathrm{Na} / \mathrm{H}$ exchange in renal microvillus vesicles in chronic hypercapnia. Kidney Int. 34:60-66. 
12. Krapf, R., R. J. Alpern, F. C. Rector, Jr., and C. A. Berry. 1987. Basolateral membrane $\mathrm{Na}$ /base cotransport is dependent on $\mathrm{CO}_{2}$ / $\mathrm{HCO}_{3}$ in the proximal convoluted tubule. J. Gen. Physiol. 90:833-853.

13. Krapf, R. 1988. Basolateral membrane $\mathrm{H} / \mathrm{OH} / \mathrm{HCO}_{3}$ transport in the rat cortical thick ascending limb. J. Clin. Invest. 82:234-241.

14. Alpern, R. J. 1985. Mechanism of basolateral membrane $\mathrm{H} / \mathrm{OH} / \mathrm{HCO}_{3}$ transport in the rat proximal convoluted tubule. J. Gen. Physiol. 86:613-636.

15. Alpern, R. J., and M. Chambers. 1986. Cell pH in the rat proximal convoluted tubule. J. Clin. Invest. 78:502-510.

16. Roos, A., and W. F. Boron. 1981. Intracellular pH. Physiol. Rev. 61:297-434.

17. Trivedi, B., and R. L. Tannen. 1986. Effect of respiratory acidosis on intracellular pH of the proximal tubule. Am. J. Physiol. 250 (Renal Fluid Electrolyte Physiol. 19):F1039-F1045.

18. Adam, W. R., A. P. Koretsky, and M. W. Weiner. 1986. 31PNMR in vivo measurement of renal intracellular pH: effects of acidosis and K-depletion in rats. Am. J. Physiol. 251 (Renal Fluid Electrolyte Physiol. 20):F904-F910.

19. Cogan, M. G. 1989. Renal acidification: integrated tubular responses. In: Handb. Physiol. Erich Windhager, editor. In press.

20. Adrogue, H. J., and N. E. Madias. 1986. Renal acidification during chronic hypercapnia in the conscious dog. Pfluegers Arch. Eur. J. Physiol. 406:520-528.

21. Brazeau, P., and A. Gilman. 1953. Effect of plasma $\mathrm{CO}_{2}$ tension on renal tubular reabsorption of bicarbonate. Am. J. Physiol. 175:3338.

22. Carter, N. W., D. W. Seldin, and H. C. Teng. 1959. Tissue and renal response to chronic respiratory acidosis. J. Clin. Invest. 38:949960.

23. Luke, R. G., and H. Levitin. 1966. The renal and electrolyte response to respiratory acidosis in the adrenalectomized rat. Yale $J$. Biol. Med. 39:27-37.

24. Polak, A., G. D. Haynie, R. M. Hays, and W. B. Schwartz. 1961. Effects of hypercapnia on electrolyte and acid-base equilibrium. I. Adaptation. J. Clin. Invest. 40:1223-1237.
25. Rector, F. C., Jr., D. W. Seldin, A. D. Roberts, and J. S. Smith. 1960. The role of plasma $\mathrm{CO}_{2}$ tension and carbonic anhydrase activity in the renal reabsorption of bicarbonate. J. Clin. Invest. 39:1706-1721.

26. Relman, A. S., B. Etsten, and W. B. Schwartz. 1953. The regulation of renal bicarbonate reabsorption by plasma carbon dioxide tension. J. Clin. Invest. 32:972-978.

27. Sapir, D. G., D. Z. Levine, and W. B. Schwartz. 1967. The effects of chronic hypoxemia on electrolyte and acid-base equilibrium: an examination of normocapneic hypoxemia and of the influence of hypoxemia on the adaptation to chronic hypercapnia. J. Clin. Invest. 46:369-377.

28. Schwartz, W. B., N. C. Brackett, Jr., and J. J. Cohen. 1965. The response of extracellular hydrogen ion concentration to graded degrees of chronic hypercapnia: the physiologic limits of the defense of $\mathrm{pH} . J$. Clin. Invest. 44:291-301.

29. Sullivan, W. J., and P. J. Dorman. 1955. The renal response to chronic respiratory acidosis. J. Clin. Invest. 34:273-282.

30. Van Ypersele de Strihou, C., P. F. Gulyassy, and W. B. Schwartz. 1962. Effects of chronic hypercapnia on electrolyte and acid-base equilibrium. III. Characteristics of the adaptive and recovery process as evaluated by provision of alkali. J. Clin. Invest. 41:22462253.

31. Makoff, D., and B. J. Rosenbaum. 1971. Adaptation to chronic hypercapnia in the potassium-depleted dog. Am. J. Physiol. 220:1724-1727.

32. Yang, W. Ch., J. A. L. Arruda, and Z. Talor. 1987. Na/H antiporter in posthypercapnic state. Am. J. Physiol. 253 (Renal Electrolyte Fluid Physiol. 22):F833-F840.

33. Akiba, T., V. K. Rocco, and D. G. Warnock. 1987. Parallel adaptation of the rabbit renal cortical sodium/proton antiporter and sodium/bicarbonate cotransporter in metabolic acidosis and alkalosis. J. Clin. Invest. 80:308-315.

34. Preisig, P., and R. J. Alpern. 1988. Chronic metabolic acidosis causes an adaptation in the apical membrane $\mathrm{Na} / \mathrm{H}$ antiporter and basolateral membrane $\mathrm{Na} /\left(\mathrm{HCO}_{3}\right)_{3}$ symporter in the rat proximal convoluted tubule. J. Clin. Invest. 82:1445-1453. 